\title{
Study on the Correlation between Taxation and Economic Growth
}

\author{
Caiyan She, Jinfeng Xu \\ Nanchang Institute of Science \& Technology, Nanchang, Jiangxi, 330008
}

Keywords: Taxation, Economic Growth, Correlation Research

\begin{abstract}
Economy is the source of taxation, its size and pace of development determine the level of tax revenue; tax on the redistribution of income, and its multiplier effect in turn affect economic growth. Therefore, tax revenue and economic output are two important indicators to measure the economic development. The study of the relationship between tax revenue and economic growth has become a common concern of economists, sociologists and political scientists.
\end{abstract}

\section{Introduction}

It is important to analyze and grasp the basic characteristics and trends of economic operation. We should be concerned about the following points. After the enlargement of the EU, investment and trade integration is gradually harmonized, the formation of new economic and trade partners, the impact on Chinese trade in Europe, the need for timely and flexible adjustment; the EU new laws, directives, such as electrical and electronic products on the instructions, The relevant departments and enterprises need to export products to the EU to do technical preparations, put forward the corresponding countermeasures. ASEAN Free Trade Zone rapid development, according to the framework of the arrangements between countries, more than 7,000 kinds of imported goods to 2010 tariff reductions between Chinese production and exports will have an important impact, should seize the opportunity to actively adjust Business strategy. With the deepening of the degree of investment and trade liberalization in various countries, under the new conditions, trade frictions and trade protection have new characteristics. Our enterprises, trade associations and relevant departments should actively respond. This is an important link in safeguarding the interests of the state and enterprises and ensuring the export trade. Protect the rights and interests of the state and corporate interests, the need to adjust the foreign trade strategy, improve and reform the tax system and mechanisms to improve tariffs and export tax rebate approach.

The level of Chinese reform and opening up into a new period of promotion. Chinese foreign trade import and export volume ranks third in the world, only 5 years to reach more than 1 trillion US dollars, many countries in the world to make economic benefits to contribute. With the development and changes of foreign trade, China has further adjusted and improved the tariff and export tax rebate system, tax policy is more adapted to the needs of opening up. Eleventh Five-Year period to provide enterprises with fair and just more relaxed tax conditions, to speed up the domestic and foreign-funded enterprises income tax two sets of the pace of tax merger, the implementation of the principle of true national treatment. Chinese economic development into a new period of opportunity. Since 2002, Chinese economy has witnessed a rapid growth, which has maintained a growth rate of over $8 \%$. The consumption price level of urban residents has continued to be low. Rapid economic growth, low inflation has emerged. In the past two years, the reform of the economic system has been progressing steadily and achieved positive results, laying the foundation for the fairness, fair competition and rapid growth of the national economy. Such as the financial system and fiscal and taxation system reform; enterprise reform and restructuring reform; 
capital market reform and stability of housing prices reform. Seize the opportunity of economic development, continue to maintain high economic growth and low inflation situation is to achieve the key link in the Eleventh Five-Year Plan. And to solve the institutional and institutional constraints, we must accelerate the taxation, finance and corporate restructuring and reform in areas such as reform is the most important.

\section{Chinese Tax Revenue and Its Influencing Factors}

Government tax revenue depends on the scope of government functions and the possibility of income. Under the framework of public finance, the basic scope of government functions mainly includes the provision of public goods. Under the special conditions of our country, the government has also assumed the functions of organizing resources and developing economic construction. The government has undertaken a lot of investment. At present, the functions of our government not only include the supply of public goods but also the investment, the development of economy. However, with the improvement of Chinese economic development and the improvement of the market economy, the process of public finance system construction in our country will be accelerated and the government function will be transferred to Provide public goods. In addition, the possibility of income depends on a certain tax system under the level of tax collection and economic growth.

At present, our government not only bears the supply of public goods, but also bears the responsibility of economic development, pursuing a fiscal policy, the government revenue growth will have a significant impact on high tax revenue. In 1994, China established a fiscal system of tax-sharing system. The huge institutional effect of tax-sharing system may be one of the main reasons to promote the high tax increase in our country. In addition, the tax system has repeatedly taxed, changes in inventory investment, tax arrears and owe and other factors are also factors that affect tax revenue.

\section{The Impact of Chinese Tax Increase on Economic Growth}

Taxation has a significant impact on investment, consumption, exports and technology, but there are significant differences in the way in which the impact of taxation on the main factors that contribute to economic growth. Investment is affected by the level of macro tax burden significantly. The effect of personal income tax on investment is obvious, and the effect of government investment on private investment is obvious. It should reduce the personal income tax and government investment, stimulate private investment, and thus promote economic growth. Technology is mainly affected by the marginal macro tax burden, the two are significantly negative correlation, the marginal macro tax burden on the impact of technology is a fixed proportion, you can reduce the marginal macro tax burden approach to promote technological innovation and new technology, improve the whole factor productivity. The effect of marginal macro tax burden on labor supply, consumption and export is influenced by the geometric multiple of the secondary curve. The decline of the marginal macro tax burden will cause the labor supply, consumption and export to change according to the multiple, among which the marginal macro tax burden and the number of urban employees Growth rate and net export growth rate was inverted U-shaped, while the marginal macro tax burden and the final consumption growth rate of residents was U-type. Personal income tax and consumer consumption is negatively related, should reduce the personal income tax burden to stimulate the consumption of residents, through personal tax relief to start domestic demand. The net tax burden of imports and exports is negatively correlated with net exports. In the current trend of slowing 
economic growth and the US financial crisis, it can stimulate net exports by reducing net import and export risks and prevent economic growth from slowing down. There is a positive correlation between the tax burden of industrial enterprises above designated size and the growth rate of the whole society. It shows that the current investment decision-making is still unreasonable, and the investment has become the source of government revenue. It may form the government's high investment in order to obtain tax revenue. The need for government tax, the two together to promote high tax revenue and corporate tax burden and investment are positively related. This cycle should be broken.

From the four economic belt stone, the specific effect of the region is very different. From the perspective of the comprehensive effect of taxation on economic growth, the eastern and central regions have positive effects, but the positive effects in the eastern part are significantly higher than those in the central part; the northeast and western regions have negative effects, but the negative effect in the west is more than that in the northeast Significantly. In other words, from the comprehensive effect of taxation on economic growth, the high tax revenue since 1994 has benefited the eastern most, and the second has benefited from the middle, but the economy has been significantly suppressed in the western region. Growth has also been a certain inhibition. Whether it is national or four economic belt, overall, the tax on the regional economic gap is not a significant shadow to. From the inside of the country and the four economic zones, tax revenue growth has led to fiscal growth, and the multiplier effect of fiscal expenditure has been expanded to promote economic growth. The positive effects of fiscal expenditure growth on economic growth are significant both at the eastern, central and national levels, and not significant in the northeast and west. Whether it is nationwide or within the four economic zones, the fiscal growth caused by tax revenue has had a significant impact on the regional economic disparity, but played a different role in the country and the economic belt, except that the central region has expanded the regional economic gap , The nationwide and other economic zones have narrowed the regional economic growth gap.

\section{Policy recommendations}

Current response to the global financial crisis China has adopted a series of tax cuts, the ultimate goal of tax cuts is to stimulate economic growth and achieve sustainable economic growth. From the macro tax burden point of view, tax policy and Chinese tax system design policy objectives should be to maintain the macro tax burden of about 20\%, to promote the optimal economic growth. Should strengthen the current GDP and tax revenue in the internal link; increase the proportion of taxable GDP in GDP, wide tax base low tax burden. Chinese tax system design should take full account of the tax selection, collocation and the main tax structure of the scientific nature, rationality, widening the scope of taxation. GDP and tax revenue growth is not close and taxable GDP is not high, and China to turnover tax as the main tax structure, should be committed to cultivating turnover tax and income tax dual subject tax structure. Turnover tax is easy to pass on, some of the tax burden should bear the tax burden, both the tax burden is unfair, but also weakened the tax revenue and current GDP link, reducing the taxable GDP ratio, so that the scope of the actual tax Shrink down. Income tax is not easy to pass, directly from the current GDP, but also conducive to ensuring the scope of tax credit, the current should be committed to cultivating turnover tax and income tax dual tax structure. 2008 corporate income tax merger, the future income tax reform should focus on personal income tax reform. The long-term goal of the personal income tax reform should be to promote the personal income tax from the classification income tax system to the comprehensive income tax system; the focus of the recent reform should be to simplify the wages 
and salaries applicable tax rate system, raise wages and salaries deduction standards, the establishment of pension, Housing, education and other pre-tax special deduction system, and so on.

Chinese government revenue includes budgetary revenues (ie, fiscal revenue), extrabudgetary income and system income, since the central authorities in 1996 to increase clean-up charges since the work, the current system has been very little income. According to whether the inclusion of NPC budget management can be divided into budget revenue and extrabudgetary income, based on whether the tax revenue can be divided into tax revenue and non-tax revenue. At present, non-tax revenue, especially extrabudgetary income management is not standardized. We should try to standardize the government revenue system, strengthen the non-tax management, promote tax reform, which is the focus and difficulty of fiscal and taxation system reform.

The incentive of the tax authorities to strengthen the collection and management to a large extent with the local government's super-return and return is not included in the budget management linked together, may lead to the national tax authorities both central and responsible for the local dual loyalty issues, serious may lead to only Local responsibility, the central income will be damaged. Should be strictly prohibited all forms of income return; strengthen the budget management, and strive to all government funds into the budget management; further improve the tax system, the tax as a tax standard, reduce the central and local shared tax, efforts to solve the tax authorities (mainly tax authorities ) Dual loyalty issues.

Chinese nominal tax rate and the actual tax rate between the huge difference is the source of tax collection and management to enhance the source, but also to the tax authorities to control the flexibility of income. In the current tax reform, it is necessary to reduce the nominal tax rate but slightly higher than the actual tax burden, the difference between the nominal tax burden and the actual tax burden. Both to ensure that the fiscal revenue, but also reduce the micro-tax burden; the same time, improve the tax compliance rate, tax revenue tax collection and management departments to control the elasticity of space, and further promote tax law.

\section{Conclusion}

In recent years, Chinese tax revenue has grown rapidly and has surpassed the growth rate of national income. This paper first elaborates the research background of taxation and economic growth. Secondly, we use the time series to analyze the causes of the abnormal growth of tax revenue, and use the vector autoregressive model to analyze the impact of tax on the economy. Finally, the empirical results show that economic growth is not the only reason for the growth of tax revenue, tax revenue growth in the long term has a positive impact on economic growth.

\section{References}

[1] Bo Wenguang. Chinese regional growth spillover effect and its differences - based on panel data empirical research [J]. Economic Science, 2008 (03)

[2] Wang Daozhen. Empirical analysis of influencing factors of tax revenue [J]. Foreign Taxation, $2008(02)$

[3] Gao Yuming, Qi Zhongying. Optimization of Total Factor Productivity Based on Time-Varying Parameters in China [J]. Journal of Economic and Technological Research, 2008 (02)

[4] Gerald W. Scully, Yuan Haoran. Optimal taxation, economic growth and income inequality [J]. Economic Information Translation, 2007 (04)

[5] Zhang Dezhi. Chinese macro tax burden reasonable level [J]. Theoretical frontier, 2007 (24) 